\title{
DUBAI CREEK ENTRANCE
}

\author{
H.RIdehalgh, F.I.C.E. \\ Partner,Sir William Halcrow and Partners \\ Consulting Engineers \\ Newcombe House, 45 Notting H11l Gate, London W.11
}

\section{INTRODUCTION}

The paper describes the works carried out to Improve and stabilise the entrance to the Creek at Dubal. The Creek which is about elght miles long discharges through a heavily charged littoral zone in which large volumes of sand are transported across the entrance from west to east.

The works were required urgently and this coupled with financial restrictions prevented a study of the problem on an hydraulic model or the collection of comprehensive site information before construction of the work commenced.

In the event the works were carried out in stages - succeeding stages being planned and designed after the effects of the previous stages on the regime had been established.

The paper presents the results which were achleved using the prototype as a model and traces the effect of each stage on the Creek and littoral regimes from the commencement of the works.

\section{GEOGRAPHICAL LOCATION}

Dubal is situated on the south eastern shores of the Arabian Gulf and on the north western coast of the Musandam peninsular at approximately parallel $25^{\circ}$ north. Fig.1. Indicates the geographical location of Dubai.

\section{HISTORICAL}

The State of Dubal is one of the seven Trucial States so called after the truce with Britain in 1820. A thriving entrepot trade has been built up over the years based on the Creek, and the desire to Improve the entrance to the Creek was manifested in 1955, in order to facilitate further expansion of the State's trade. The improvement works required were essentially to deepen and stabilise the entrance to the Creek so that unrestricted access at all stages of the tide and during most weather conditions would be possible. The works were commenced in 1959 and completed in 1961/62. 
WEATHER

The weather can be divided into the two seasons - winter and summer. The winter is characterised by temperate condltions with light winds mainly from the N.W. Squalls of short high intensity, with wind strengths up to force 7 and sometimes greater are experienced. In the summer, hlgh temperatures persist with falrly strong constant winds from the $\mathrm{I} . \mathrm{W}$. In the afternoon this wind is normally about force 3 or 4 on $70 \%$ of the days. The wave front conforms with the prevaling wind. What little rainfall there is usually falls in the winter, otherwise arld desert conditions prevail.

\section{PHYSICAL FEATORES}

Fig.1. shows the general boundaries of the Creek which is about elght mlles lons. The southern shores are generally steep slded and ringed with soft sand or sand dunee, whllst the northern shores are generally gently shelving and almost devold of soft sand, indicating that the Creek traps most of the wind borne sand.

The bed of the Creek varles from hard layers of cemented sand and shells to deposits of fine grey sand. In general the hard layers are only a few Inches thlck and exist at varıous levels in the Creek, overlain by sand where accretion is taking place and exposed where erosion is dominant. The hard layer effectively prevents further erosion.

Fig.2. indrates the configuration of the entrance at about the time when the Author first became involved. At that time the ebb flowed away eastwards through several small unstable channels in a shallow coastal zone with the velocity of about half a knot.

The sea bed outside the Creek consists of sand, cemented sand and small areas of live coral, although the area immediately outside the old entrance was predominantly moblle sand.

The coastline is generally flat and sandy with a coastal barrier of sand dunes penetrated by a number of inlets connecting to lagoons behind the barrier.

The inlets are all unstable and appear to evolve cyclically; the entrance to Dubal being one such inlet. The coast is generally low lying and extensıve areas of salt flats exist in aseociation with the lagoons behind the barrier of sand dunes.

The direction of littoral drift is from west to east and longshore currents of up to one knot have been recorded off the entrance.

The tidal range in the open sea is of the order of five feet and that within the Creek was about three feet before the works were constructed, high water and low water generally lagging behind those of the open sea; low water lagging approximately twice as much as high water. 


\section{THE WORKS AND THEIR PERFORMANCE}

The first phase works consisted of dredging a channel some 3,000 feet long and down to six feet below low water through the sand spit as far as the one fathom (six feet) contour in the open sea and the closing of the 1954 and 1957 channels by the construction of a training wall some 1,000 feet long aligned to encourage both ebb and flow to follow the same path. At the same time a groyne was constructed with the intention of protecting the entrance and encouraging accretion on the eroding Shindagah foreshore, as well as to prevent bar formation across the entrance. Fig.3. Indicates these proposals. The dredgings were used to ranse the level of the low lying area behind Shindagah.

The dredging was lumited to six feet below low water by reason of the presence of a hard layer of cemented sand just below this level, the cost of removal of which would have been out of proportion to the benefit received.

It was decided at that time that the quickest and most economic form of construction in these conditions for the groyne and the training wall would be a steel sheet piling and this has remained the case up to the present day.

Even though Creek discharge velocity increased to about three feet per second, these works were only partially successful, and Fig. 4. illustrates the conditions existing at their conclusion, from which it will be seen that further works were necessary.

The bar across the entrance was formed largely as a result of bed and bank erosion within the Creek itself. In particular, large quantities of sand were eroded from the bank at Ras Dalra due to the realignment of the entrance and the increased current velocities. the littoral drift naturally contributed to the bar formation, but probably more to the shape than to the size of the bar. At this stage the Shindageh foreshore some distance upstream was beginning to erode due to the influence of the groyme.

Conditions at the entrance which remalned navigable for about nine months deteriorated suddenly as a result of a prolonged storm during which the bar was supplemented overnight by an accretion of approximately 100,000 cubic yards, and it became imperative to supplement the works already completed.

It was decided, therefore, to extend the groyne seawards into deeper water in an attempt to reduce the effect of the drift and further protect the entrance. At the same time the training wall was extended inland to encompass the eroding bank at Daira, and so prevent the transport of material from this particular bank to the entrance and, at the same tıme, it was extended seawards to direct the discharge further out into the littoral drift. By this means discharge velocity was increased to about five feet per second. Fig. 5. shows the Phase II proposals which, in the event, proved most successful and the conditions at the entrance after completion of the work are shown on $\mathrm{Fig} \cdot 6$. 
The groyne was successful in arresting the drift, and this may well have been fundamental to the success of the scheme in that shelter from the weather and littoral drift facilitated the completion of the rest of the works and enabled the transport of sediment from the Creek to take place under relatively stable conditions without conflict with the littoral stream.

The entrance condition as it stands today is quite stable. The velocity has been improved to a maximum of about five knots and the shoal show on Fig.6. has moved further east Improving access to the entrance. The groyme is now full and materlal is pessing across the entrance to the shoal on the eastern side of the entrance.

\section{SIDE EFFECTS}

The Phase II works having been completed and a permanent feature of the coastline having been formed, several side effects appeared.

The principal effect was the erosion of both the Shindagah foreshore and that of Ras Daira.

Whlst the main groyme was able to halt erosion immediately adjacent to It severe erosion took place some distance upstream along the beach. Four concrete groynes were erected which effectively controlled the loss and eventually sufficient accretion was encouraged to replace the beach previously lost.

Eventually 1 t was found necessary to increase the number of groynes to cover a distance of approximately one mile westwards along the beach, 1.e. sufficiently far to be outside the effect of the new entrance.

Erosion on the beach further downstream did not manifest itself untjl some time after the Phase II works were complete. Erosion of the beaches much further east of Dubai has been going on for many years and will eventually become a problem, although at the present time this area of the coast is uninhabited. The beach in this area 18 subjected to waves from a more northerly direction, due to the influence of the entrance and refraction by the beach contours. The submerged offshore bar comprising the cut-off remains of the old sand splt effectively prevented erosion until the bar itself was eroded, whereupon shore erosion became progressively worse. Four groynes have been erected as an interim measure which have, to a large extent relieved the situation.

The Increased discharge velocity of the Creek undoubtedly contributes substantially to the freedom from shoaling at the entrance but, in addition, It is thought that the very high salinity in the upper Creek induces a reversal of normal estuarine flow conditions which also contributes to the absence of bar formation. 
It is thought also that the orientation of the end section of the groyne in relation to the normal wave front is such as to produce a small inshore current which tends to hold back the drift. Further west along the coast where the effect of this current is no longer felt, there appears to be some accretion of the beach which might well be the beginning of a new sand spit.

GENERAL

The stage development followed, when using the prototype as a model has, in fact, produced a result of the classical style resulting when a discharge takes place into or through a littoral stream. Accretion and some denudation has taken place on the upstream side and erosion has become evident on the downstream side. There are signs also that some of the accretion on the upstream side is now beginning to find its way into the entrance, although the discharge velocity is still able to maintain a channel free from shoaling.

It could well be argued that the works have made no contribution to the solution of the problem, and that further extensions seawards of both groyme and training well will be necessary.

This may be true but should be considered in relation to the economic advantages gained by building the entrance in its present form. Trade into the Port has increased four-fold as a result of the new entrance, and has produced a very substantial revenue. Further, considerable sums of money have been derived from the sale of reclamed areas within the Creek, and it could be said that the scheme has already proved its economlc viabllity. In addltion there has been a financial and time saving due to using the prototype as a model.

The income derived as a result of the new entrance, together with newly acquired oil revenues, have resulted in a decision to build a new deep water artiflcial port, approximately two miles upstream of the orlginal entrance. An hydraulic model has now been built to determine the effects this new port will have on the coastal regime, and consideration will be given during these investigations to the desirability or otherwise of maintaining the present entrance and protecting the adjoining coastal areas.

It is hoped that it will eventually be possible to discharge the Creek through the new Port, in which case any coast protection works built now to safeguard the position resulting from the construction of the present entrance would either be redundant or inappropriate. 


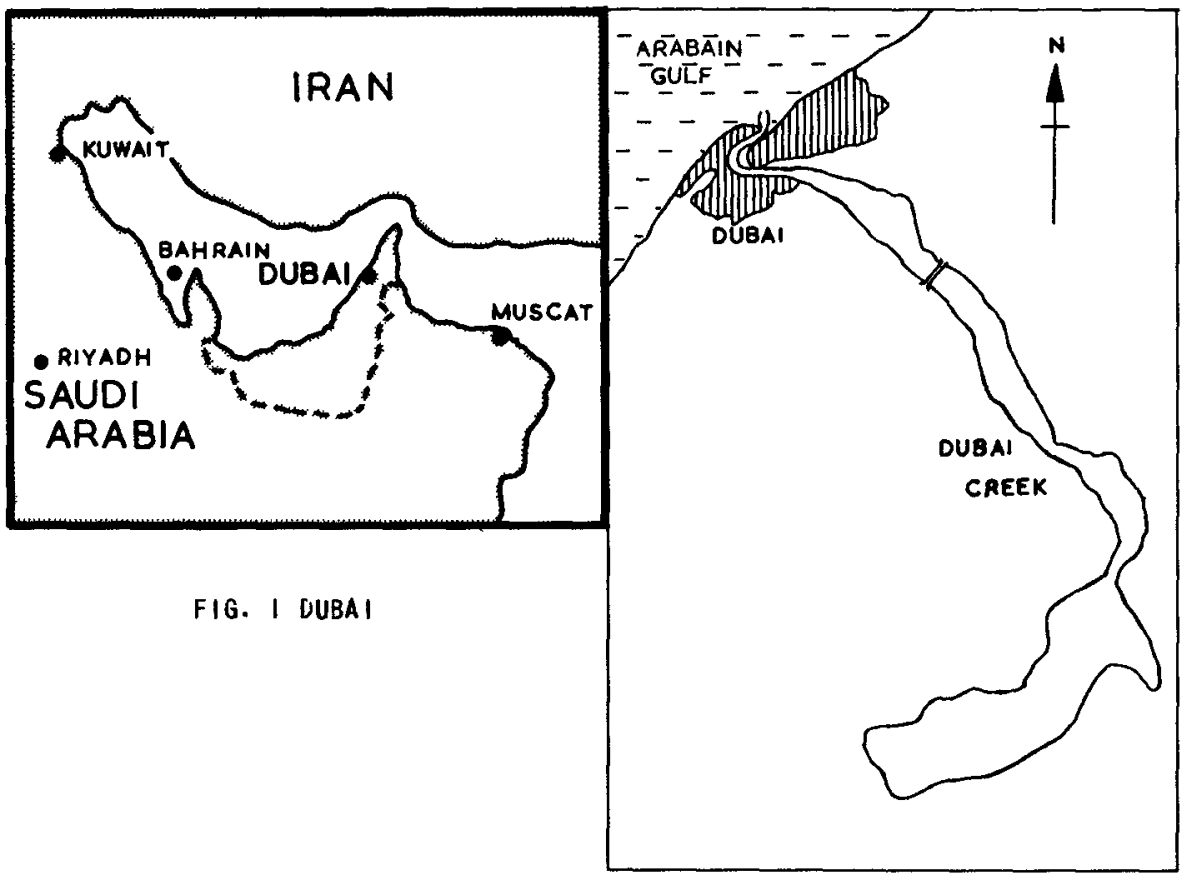




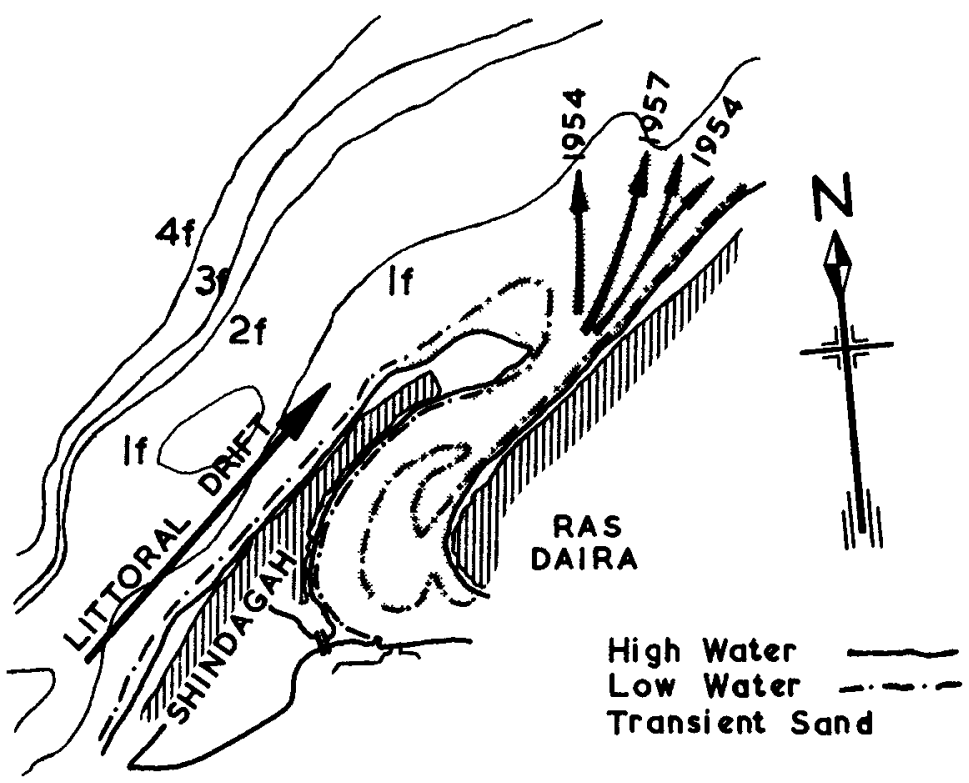

FIG. 2 DUBAI ENTRANCE BEFORE COMMENCEMENT OF WORKS

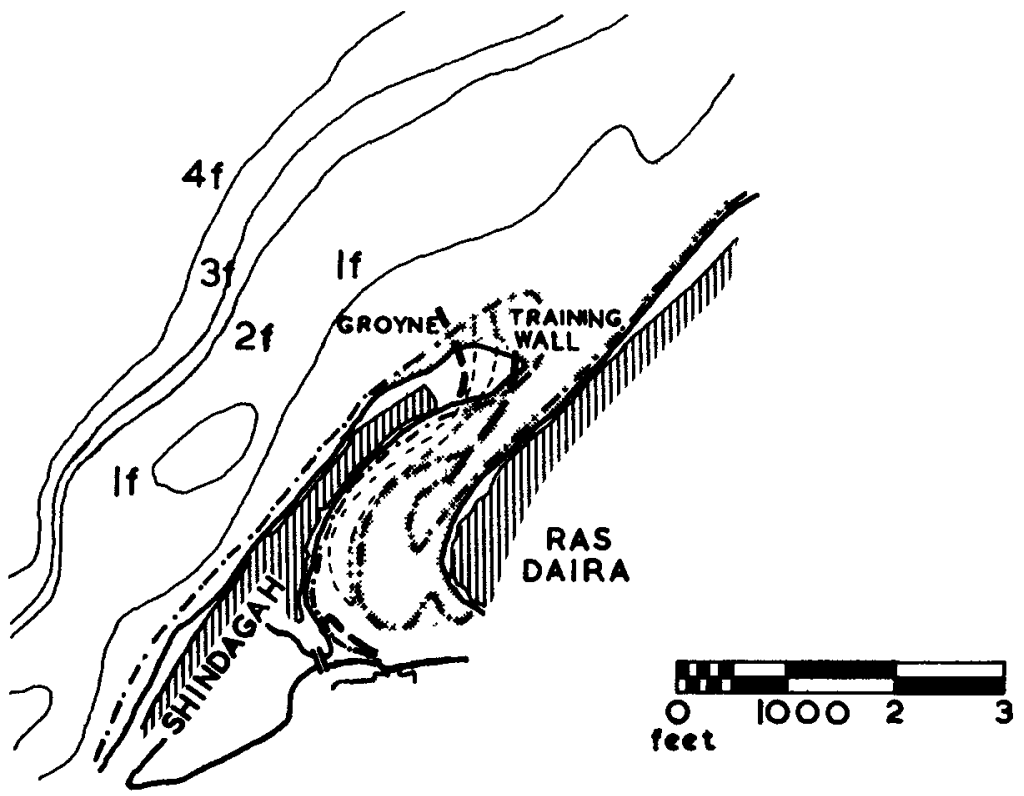

FIG. 3 DUBAI CREEK EMTRANCE PHASE I PROPOSALS 


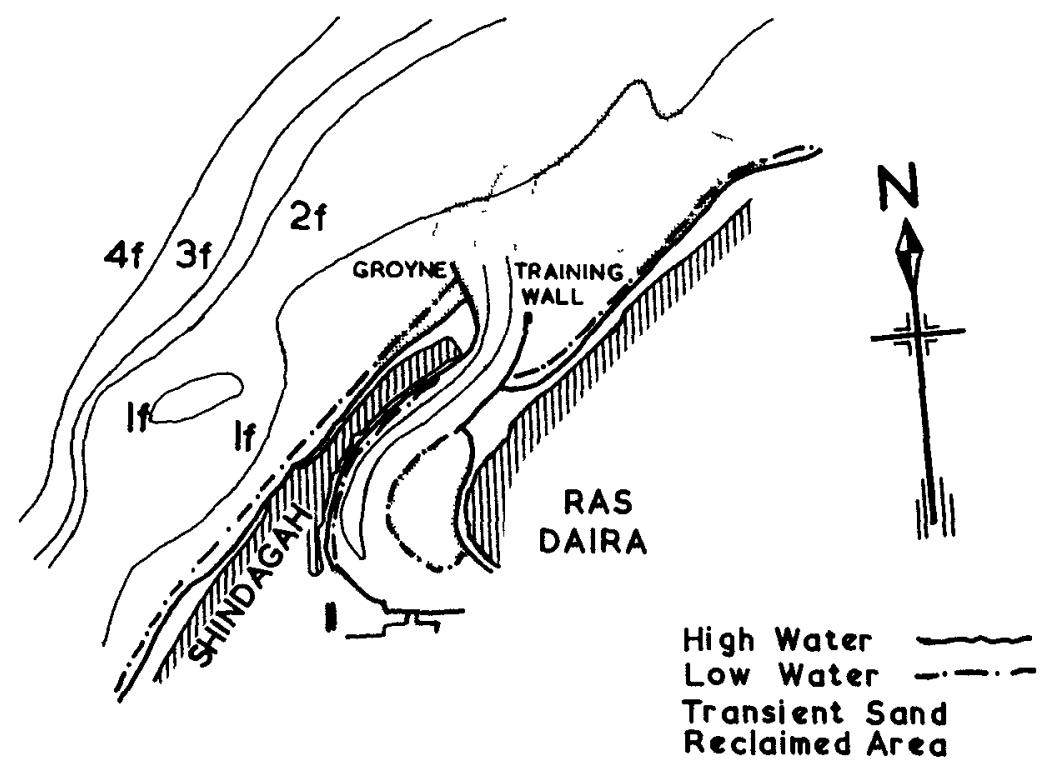

FIG. 4 DUBAI CREEK ENTRANCE AFTER COMPLETION OF PHASE I WORKS



F16. 5 dubaI CREek entrance Phase 11 proposals 


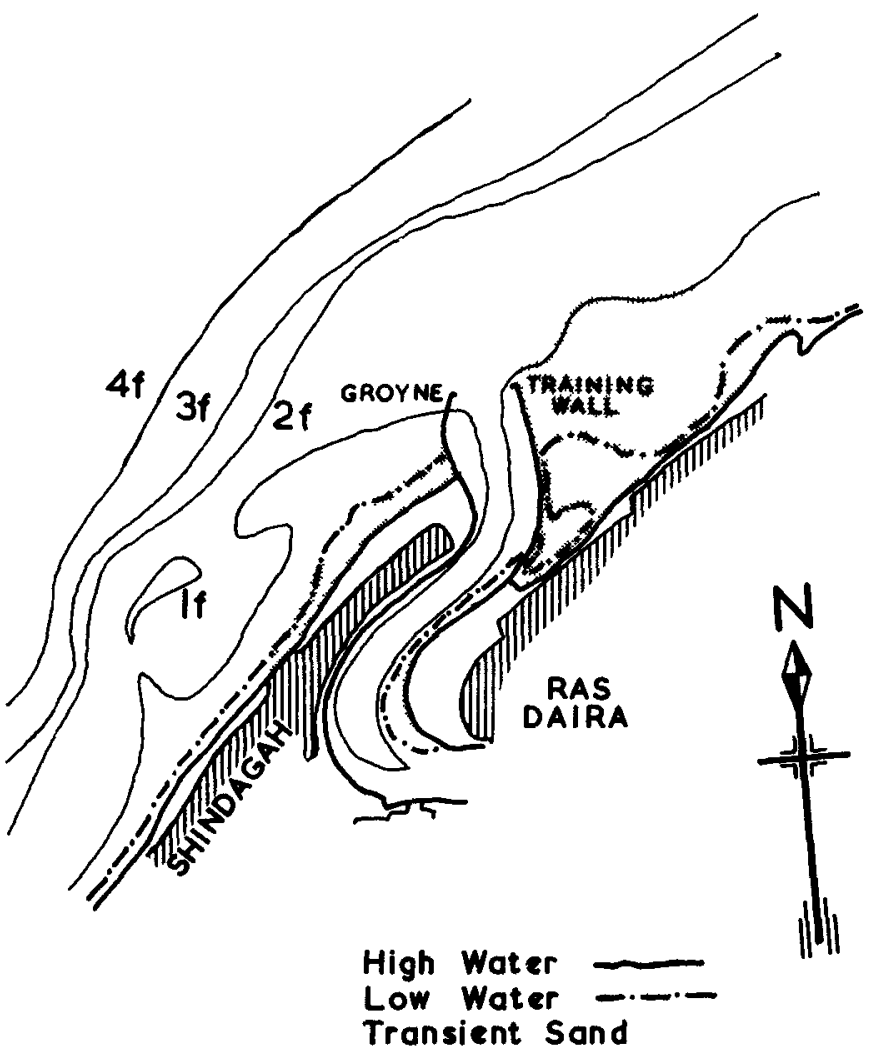

FIG. 6 DUBAI CREEK ENTRANCE AFTER COMPIETION OF PHASE II WORKS 